\title{
Altered tissue content of trace metals in diabetic hyperinsulinaemic sand rats (psammomys obesus)
}

\author{
I. Raz ${ }^{1}$, J.H. Adler ${ }^{2}$ and E. Havivi ${ }^{3}$ \\ ${ }^{1}$ Department of Medicine B, 2 Department of Physiology and \\ ${ }^{3}$ Center for Preacademic Studies, The Hebrew University, Hadassah Medical School, Jerusalem, Israel
}

Summary. The concentrations of zinc, copper, and chromium in liver, kidney, muscle, bone and serum from control normoinsulinaemic and hyperinsulinaemic sand rats (Psammomys obesus) and from untreated spontaneously hyperinsulinaemic-hyperglycaemic sand rats were compared. A chronic hyperinsulinaemic-hyperglycaemic state was associated with a significant reduction $(p<0.01)$ of zinc concentration in the liver, kidney and muscle but an elevation of zinc content in bone and of chromium in the liver. A hyperinsulinaemic-nor- moglycaemic state was not associated with similar changes in zinc concentration in the liver, kidney, muscle and bone. We conclude that in hyperinsulinaemic-hyperglycaemic sand rats there is a tendency to zinc depletion in several tissues. This depletion is not solely the result of a hyperinsulinaemic state but may be related to accompanying hyperglycaemia.

Key words: Sand rats, trace metals, zinc, copper, chromium, diabetes mellitus.
Observations during the past two decades have demonstrated that a diabetes-like condition can result from deficiency of certain trace metals in the diet [1-3]. These trace metals (mainly zinc) have also been shown to alter the action of insulin at the receptor level [1, 4].

The effect of diabetes on zinc status was examined thoroughly in rats with streptozotocin diabetes [5-8], and in BB Wistar rats [9], both characterised by insulin deficiency. In these animals it has been shown that, in spite of increased urinary loss of zinc and copper, the content of these metals in various tissues was increased. These findings raised the possibility that hyperinsulinaemia can reverse these changes and cause a state of trace metal deficiency in various tissues.

To the best of our knowledge, only one study of trace metals in various tissues of hyperinsulinaemichyperglycaemic animals has been reported [10]. This study demonstrated the existence of zinc deficiency in the plasma and femur of diabetic mice [10].

Depressed serum zinc concentration was also found in some patients with Type 2 (non-insulin-dependent) diabetes. The zinc deficiency in these patients appeared to be the result of excessive urinary loss and impaired absorption [11].

Some patients with Type 2 diabetes and relatively low serum zinc levels were also shown to have impaired leukocyte function that was improved after zinc supplementation [12].
The purpose of our study was to evaluate zinc, copper, and chromium concentrations in various internal organs of diabetic sand rats and to establish whether hyperinsulinaemia alone or hyperinsulinaemia with hyperglycaemia is associated with changes in the trace metal content. Sand rats tend to develop hyperinsulinaemia when transferred to a diet of high caloric density (e.g. from a $50 \%$ salt bush to $25 \%$ salt bush diet), and hyperinsulinaemia with hyperglycaemia when maintained on ordinary laboratory chow only $[13,14]$.

\section{Materials and methods}

Hebrew University sand rats (Psammomys obesus) were used in this experiment. Our sand rat colony was established in 1969 from specimens collected in the Dead Sea area. Since then, a strict minimal inbreeding program has been maintained, with the colony being closed to outside breeding stock. The colony is maintained on pelleted "Amrod 935" (Anbar Mills, Hedera, Israel) animal chow and fresh or frozen salt bush ad libitum. The composition of the Amrod 935 chow by weight is: moisture $11.7 \%$, protein $17.3 \%$, fat $4 \%$, available carbohydrate $49.9 \%$ (mainly alfalfa meal $20 \%$, corn $11 \%$, and barley meal $14.4 \%$ ), fibre $8.3 \%$, ash $8.1 \%$, phytate $9.3 \mathrm{mg} / \mathrm{g}$, zinc $64.9 \mathrm{mg} /$ $100 \mathrm{~g}$, copper $1042 \mathrm{\mu g} / 100 \mathrm{~g}$ and chromium $109 \mu \mathrm{g} / 100 \mathrm{~g}$. The $50 \%$ salt bush meal contains: moisture $7.7 \%$, protein $7.0 \%$, ash $13.5 \%$, fat $1.5 \%$, available carbohydrate $38.0 \%$, fibre $31.7 \%$, phytate $10.6 \mathrm{mg} / \mathrm{g}$, zinc $94.9 \mathrm{mg} / 100 \mathrm{~g}$, copper $2730 \mu \mathrm{g} / 100 \mathrm{~g}$ and chromium $208 \mu \mathrm{g} /$ $100 \mathrm{~g}$. The animals were supplied with water ad libitum and maintained on a 12-h dark-light cycle, and ambient temperature of $28 \pm 1^{\circ} \mathrm{C}$. 
Table 1. Glucose homeostasis in the diabetic and non-diabetic sand rats

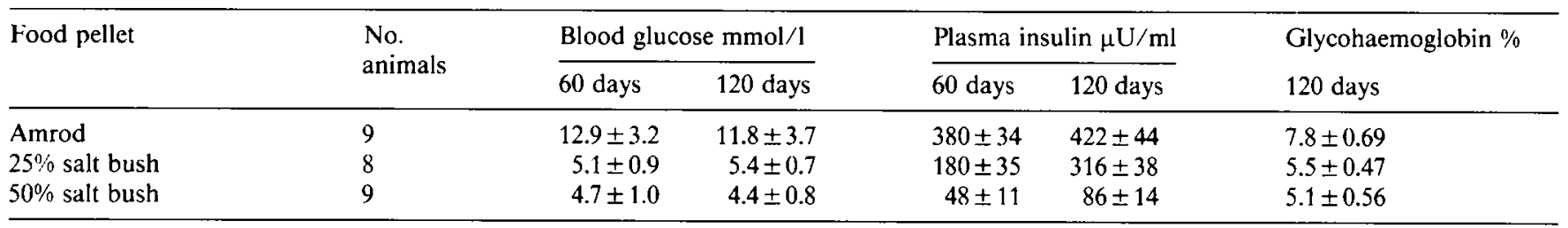

Follow up of non-fasting blood glucose, plasma insulin, and glycohaemoglobin levels in the hyperinsulinaemic-hyperglycaemic, hyperinsulinaemic-normoglycaemic and normoinsulinaemic-normoglycaemic sand rats during 120 days. Values are mean \pm SD for the number of animals indicated

Table 2. Total consumption of trace metals in the food (120 days)

\begin{tabular}{lccc} 
& Amrod 935 & $\begin{array}{c}+25 \% \\
\text { Salt bush }\end{array}$ & $\begin{array}{c}+50 \% \\
\text { Salt bush }\end{array}$ \\
\hline Zinc $(\mathrm{g})$ & 3.59 & 3.60 & 3.2 \\
Copper $(\mathrm{mg})$ & 57.5 & 72.6 & 75.4 \\
Chromium $(\mathrm{mg})$ & 60.1 & 66.4 & 63.4 \\
\hline
\end{tabular}

Total consumption of zinc, copper and chromium during 120 days per sand rat in the hyperinsulinaemic-hyperglycaemic, hyperinsulinaemic-normoglycaemic and normoinsulinaemic-normoglycaemic sand rats

Detailed information on sand rats and their tendency to develop a hyperinsulinaemic-hyperglycaemic state while on "Amrod 935" diet was reported recently $[13,14]$. For the present experiments 30 male weaning pups, 21-23 days old, were divided into 3 groups. Group 1 was fed "Amrod 935" chow only. Group 2 received pellets containing 25\% shade-dried salt bush meal and 75\% "Amrod 935", and Group 3 was offered pellets containing $50 \%$ shade-dried salt bush meal and " $50 \%$ Amrod 935". When 4 months old, the animals were anaesthetised with nembutal, $2 \mathrm{ml}$ of blood was collected from the abdominal aorta, the animals were then exsanguinated and the liver and kidney were perfused with saline to minimise blood residue in these tissues. The following tissue were dissected immediately for mineral analysis: liver, kidney, muscle (quadriceps), and femur. Visible fat was removed from the tissues. Tissues were weighed and stored in acid washed polyprophylene tubes. Tissues were then dried in preweighted porcelain crucibles for $20 \mathrm{~h}$ at $105^{\circ} \mathrm{C}$ to determine dry weight. Samples were ashed in a muffle furnace at $450^{\circ} \mathrm{C}$ for $24 \mathrm{~h}$. Residual ash was solubilised in $1 \mathrm{~mol} / 1 \mathrm{HCl}$. Zinc, copper and chromium were measured by atomic absorption spectrophotometry (Perkin Elmer Model 403, Norwalk, Conn, USA). Standards were prepared and analysed in parallel to assess recovery. The recoveries of metals (added before ashing) in the standard reference material exceeded $96 \%$. Zinc, copper and chromium content was reported as $\mu \mathrm{g} / \mathrm{g}$ dry tissue. Plasma glucose was determined with a glucose oxidase method [15]. Plasma insulin was immunoassayed with an insulin MAIA kit from Serono Diagnostics (Milan, Italy). Glycohaemoglobin was determined by the thiobarbituric acid colorimetric assay $[15,16]$ (normal range in sand rats $4.0-6.5 \%$ ).

\section{Statistical analysis}

Data are presented as means \pm SD and were statistically evaluated by the Student's t-test for nonpaired series.

\section{Results}

The blood glucose glycohaemoglobin and plasma insulin levels during 120 days of follow-up are listed in Table 1.
The daily water and food consumption of the sand rats fed the salt bush free diet at the end of the study was increased by $160 \%$ and $124 \%$, respectively, compared with the animals fed a $25 \%$ salt bush diet and by $172 \%$ and $138 \%$ compared to the sand rats fed a $50 \%$ salt bush diet (normoinsulinaemic-normoglycaemic sand rats). The mean daily consumption of trace elements by the various groups is presented in Table 2 . It can be seen that the consumption of all the trace metals was similar in the 3 groups except for copper which was consumed less in the hyperglycaemic group. The weight at the end of the study was $229 \pm 11 \mathrm{~g}, 240 \pm$ $10 \mathrm{~g}$ and $216 \pm 8 \mathrm{~g}$ in the hyperglycaemic-hyperinsulinaemic, normoglycaemic-hyperinsulinaemic and normoglycaemic-normoinsulinaemic sand rats respectively $(229 \pm 11$ vs $240 \pm 10, p<0.05 ; 229 \pm 11$ vs $216 \pm 8, p<$ $0.01 ; 240 \pm 10$ vs $216 \pm 8, p<0.001$ ). The wet and dry weight of the various tissues in which trace metal concentration was measured, are presented in Table 3. Table 4 demonstrates the concentration of zinc, copper and chromium, in the serum, liver, kidney, femur, and muscle of the sand rats.

It can be seen that zinc concentration per $g$ dry weight was significantly lower in the liver, kidney, and muscle of the hyperglycaemic sand rats compared with the normoglycaemic rats. However, zinc concentration in the femur was slightly but significantly higher $(p<$ 0.05 ) in the femur of the diabetic sand rats and the chromium level was much higher in the liver of the diabetic sand rats $(p<0.01)$. A comparison between the normoglycaemic-hyperinsulinaemic and the normoglycaemic-normoinsulinaemic sands rats (Table 5) demonstrated a very similar concentration of zinc, copper, and chromium in the liver, kidney, muscle and bone of both groups.

\section{Discussion}

The results of our study, concerning the influence of untreated diabetes on tissue concentration of trace metals in diabetic sand rats, raise the possibility that trace metal metabolism in the hyperinsulinaemic-hyperglycaemic state is different from that seen in the hypoinsulinaemic-hyperglycaemic state of insulin-dependent rats or mice. It should be metioned that the animals in our study were not pair-fed due to the pecu- 
Table 3. Tissue weight of diabetic and non-diabetic sand rats

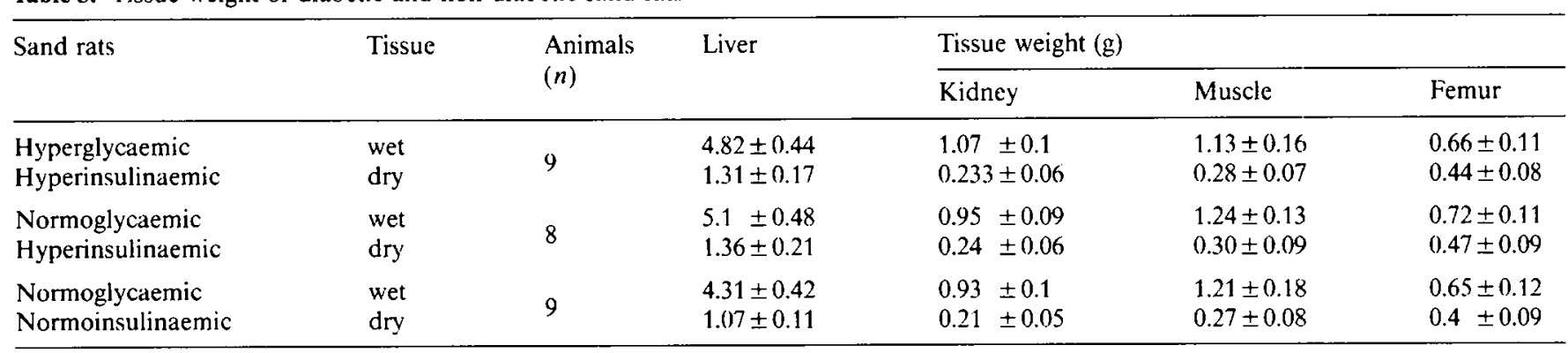

Organ weights in hyperinsulinaemic-hyperglycaemic, hyperinsulinaemic-normoglycaemic and normoinsulinaemic-normoglycaemic sand rats at the end of the study. Values are means $\pm S D$ for the numbers of animals indicated.

Table 4. Zinc, copper and chromium concentrations in serum and tissues of diabetic and non-diabetic sand rats

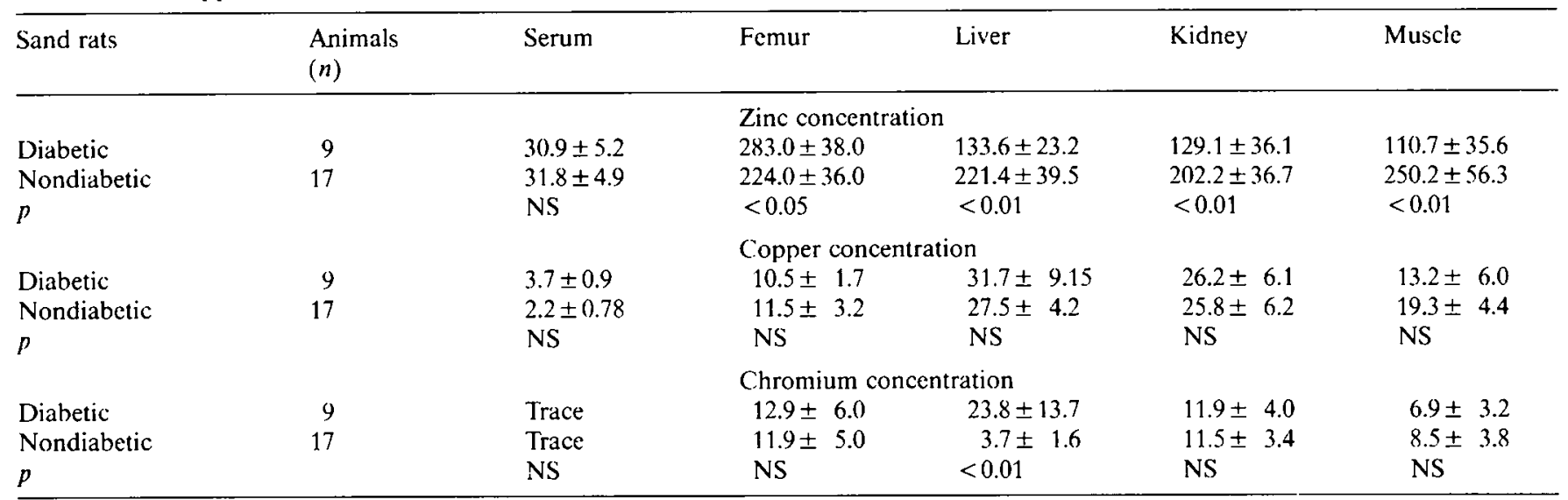

Concentration of zinc, copper, and chromium in serum ( $\mu \mathrm{mol} / \mathrm{l})$ and in femur, liver, kidney, and muscle ( $\mu \mathrm{g} / \mathrm{g}$ dry tissue) of the diabetic (hyperinsulinaemic-hyperglycaemic) and the non-diabetic (hyperinsulinaemic-normoglycaemic, normoinsulinaemic-normoglycaemic) sand rats at the end of the study. Values are mean \pm SD for the numbers of animals indicated. NS $=$ not significant

Table 5. Zinc, copper and chromium concentration in tissues form the non-diabetic hyperinsulinaemic and normoinsulinaemic sand rats

\begin{tabular}{lllll}
\hline & Femur & Liver & \multicolumn{1}{l}{ Kidncy } & Muscle \\
\hline & & \multicolumn{2}{l}{ Zinc concentration } \\
Hyperinsulinaemic & $235.7 \pm 36.0$ & $239.4 \pm 51.0$ & $200.7 \pm 39.0$ & $228.0 \pm 59.0$ \\
Normoinsulinaemic & $214.0 \pm 36.0$ & $197.0 \pm 32.0$ & $204.7 \pm 34.0$ & $266.0 \pm 54.0$ \\
$p$ & $\mathrm{NS}$ & $\mathrm{NS}$ & $\mathrm{NS}$ & $\mathrm{NS}$ \\
& \multicolumn{5}{c}{ Copper concentration } \\
Hyperinsulinaemic & $8.7 \pm 2.5$ & $30.7 \pm 4.6$ & $23.8 \pm 5.5$ & $15.0 \pm 3.0$ \\
Normoinsulinaemic & $14.0 \pm 3.7$ & $24.7 \pm 3.8$ & $27.6 \pm 6.1$ & $23.7 \pm 5.9$ \\
$p$ & $\mathrm{NS}$ & $\mathrm{NS}$ & $\mathrm{NS}$ & $\mathrm{NS}$ \\
& \multicolumn{5}{c}{ Chromium concentration } \\
Hyperinsulinacmic & $11.0 \pm 6.4$ & $5.7 \pm 2.3 \quad 10.3 \pm 3.0$ & $8.0 \pm 3.5$ \\
Normoinsulinaemic & $12.6 \pm 4.2$ & $2.0 \pm 0.8$ & $13.7 \pm 3.8$ & $9.0 \pm 4.0$ \\
$p$ & $\mathrm{NS}$ & $\mathrm{NS}$ & $\mathrm{NS}$ & $\mathrm{NS}$ \\
\hline
\end{tabular}

Concentrations of zinc, coppcr, and chromium ( $\mu \mathrm{g} / \mathrm{g}$ dry tissue) in the femur, liver, kidney, and muscle of the hyperinsulinaemic-normoglycaemic $(n=8)$ and the normoinsulinaemic-normoglycaemic $(n=9)$ sand rats, at the end of the study. Values are mean \pm SD for the numbers of animals indicated

liar diet: free access to food was necessary to induce in the sand rats the diabetic states.

In spite of the differences in the content and the amount of food consumed by each group, the amount of zinc and chromium consumed by each of the 3 different groups was very similar while the consumption of copper in the diabetic sand rats was approx. $75 \%$ of that in the nondiabetic sand rats.

The diabetogenic diet (Amrod 935) was relatively rich in protein and low in fibre and phytate when compared with the non-diabetogenic diet $(50 \% \mathrm{Am}$ rod $935+50 \%$ salt bush). Protein is known to enhance zinc absorption [17] while fibre and phytate inhibit its absorption [18, 19]. Thus, we would expect a better absorption of zinc from the diabetogenic diet and the decreased content of zinc in the various tissues of the diabetic sand rats is unlikely to be attributed to a reduced zinc availability.

Previous studies demonstrated that in the insulindependent rats and mice, zinc, copper and chromium absorption and excretion was generally elevated [20], and the concentration of these metals in various tissues such as liver, kidney and bone tended to increase as well [5-9]. The knowledge about trace metal absorption and secretion in the hyperglycaemic-hyperinsulinaemic state is much more limited. It was shown that the increased urinary zinc and copper excretion in insulin-dependent rats could be reversed by the administration of insulin $[9,21]$, and infusion of insulin to normal dogs inhibited urinary zinc excretion, while somatostatin infusion induced zincuria [22]. These findings 
support the notion that in the hypoinsulinaemic-hyperglycaemic state the alterations in trace metal metabolism and concentration resulted mainly from the lack of insulin.

Endocrine imbalance, mainly hypoinsulinaemia causing an elevation of metallothionein, is still thought to be a major contributor to the alterations of trace metal metabolism and concentrations in streptozotocin-induced and BB-diabetic rats. In obese non-insulin-dependent mice and in the diabetic sand rats insulin levels increase, so that an opposite direction of trace metal metabolism and concentration would be expected. In our study the concentration of zinc in the liver, muscle and kidney of the hyperglycaemic-hyperinsulinaemic sand rats was reduced as expected, contrary to its elevated concentration in these organs in insulin-dependent animals. However, zinc concentration in the femur was increased similarly to the findings reported in the insulin-dependent animals.

These unusual findings differ from a previous study, which demonstrated that in zinc-deficient animals the serum and bone zinc contents were generally reduced, while its concentration in the liver and kidney was only minimally altered [23]. It is possible that in the sand rat, zinc deficiency is first manifested in the liver, kidney and muscle.

Chromium concentration was reported to be low in the liver and hair of patients with Type 1 (insulin-dependent) diabetes $[24,25]$ and in the femur of insulindependent rats [6]. In our study, chromium concentration in the liver of the hyperglycaemic sand rats was more than six-fold higher than that of the normoglycaemic control rats.

The imbalance between the elevated zinc concentration in the femur, and its reduced concentration in the other organs, and the unusually high concentrations of chromium in the liver of hyperglycaemic sand rats in spite of normal concentration in the other organs, could be explained by a selective influence of the hyperglycaemic-hyperinsulinaemic state on the ability of different organs to extract these trace metals. This assumption is strengthened by the study of Eriksson et al. [26] who demonstrated that foetuses of diabetic rats were severely zinc deficient, in spite of increased zinc concentration in the maternal liver.

We anticipated that a hyperinsulinaemic state in hyperinsulinaemic-normoglycaemic sand rats would result in a similar concentration of trace metals as was seen in the hyperinsulinaemic-hyperglycaemic sand rats. Unexpectedly, the concentration of zinc in the liver, kidney, muscle and bone of the hyperinsulinaemicnormoglycaemic sand rats was similar to that of the normoinsulinaemic-normoglycaemic animals. This finding opposes our assumption that the differences in the various tissue trace metal concentration between insulin-dependent and non-insulin-dependent animals are mediated solely by the difference in insulin concentration. It is possible that the main factor determin- ing trace metal absorption and tissue storage is the hyperglycaemia in association with a lack, or excess of, insulin.

In conclusion, our data suggest that in non-insulindependent diabetes there is a tendency to zinc depletion in various organs, e.g. liver, kidney and muscle.

Toxicity of hyperglycaemia per se has been recently observed with respect to pancreatic B-cell function and insulin resistance [27] refrectoriness to insulin action on glucose transport and metabolism in muscle cells [28] and adipocytes [29]. It is possible that hyperglycaemia may interfere with cellular metal absorption as well, a suggestion that warrants further investigation in animals and patients with non-insulin-dependent diabetes to clarify the importance of glycaemia vs insulinaemia on trace metal metabolism.

\section{References}

1. Arquilla ER, Packer S, Tarmas W, Miyamoto S (1978) The effect of zinc on insulin metabolism. Endocrinology 103: 1440 1449

2. Roth H, Kirchgessner M (1981) Zinc and insulin metabolism. Biol Tr El Res 3: 13-32

3. Schroeder HA (1966) Chromium deficiency in rats: a syndrome simulating diabetes mellitus with retarded growth. J Nutr 88: 439-445

4. Coulston L, Dandonna P (1980) Insulin-like effect of zinc on adipocytes. Diabetes 29:665-667

5. Failla ML, Kiser RA (1981) Altered tissue content and cytosol distribution of trace metals in experimental diabetes. J Nutr 111: 1900). 1909

6. Rosholt MN, Hegarty PVJ (1981) Mineralization of different bones in streptozotocin-diabetic rats: study on the concentration of light minerals. Am J Clin Nutr 34: 1680-1685

7. Failla ML, Kiser RA (1983) Hepatic and renal metabolism of copper and zinc in the diabetic rat. Am J Physiol 244: E113-E121

8. Raz I, Havivi E (1988) Influence of chronic diabetes on tissue and blood cells status of zinc, copper, and chromium in the rat. Diabetes Res 7: 12-19

9. Failla ML, Gardll CYR (1985) Influence of spontaneous diabetes on tissue status of zinc, copper and manganese in the BB Wistar rats. Proc Soc Exp Biol Med 180: 317-322

10. Levine AS, McClain CJ, Handwerger BS, Brown DM, Morley JE (1983) Tissuc zinc status of genetically diabetic and streptozotocin-induced diabetic mice. Am J Clin Nutr 37: 382-386

11. Kinlaw WB, Levine AS, Morley JE, Silvis SE, McClain CJ (1983) Abnormal zinc metabolism in Type II diabetes mellitus. Am J Med 75: 273-277

12. Niewochner CB, Allen JI, Boosalis M, Levine AS, Morley JF (1986) Role of zinc supplementation in Type II diabetes mellitus. Am J Med 81: 63-68

13. Adler JH, Lazarovici GO, Marton M, Levy E (1986) The diabetic response of weaning sand rats (Psammomys Obesus) to diet containing different concentrations of salt (Atriplex alimus). Diabetes Research 3: 169-171

14. Kalderon B, Gutman A, Levy E, Shafrir E, Adler JH (1986) Characteriztion of stages in development of obesity-diabetes syndrome insand rat (Psammomys obesus). Diabetes 35: 717-724

15. Marks V (1959) An improved glucose oxidase method for determining blood, CSF and urine glucose levels. Clin Chim Acta 4: $395-400$

16. Parker KM, England JO, Da-Costa J, Hess RL, Goldstein DE (1981) Improved colorimetric assay for glycosylated hemoglobin. Clin Chem 27: 669672 
17. Greber JL, Shedeker SM (1980) Effect of dietary protein and phosphorous levels on the utilization of zinc, copper, and manganese. J Nutr 110: 2243-2253

18. Kelsay JL, Jacob RA, Prathers ES (1979) Effects of fiber from fruits and vegetables on metabolic responses of human subject. III. Zinc, copper and phosphorous balances. Am J Clin Nutr 32: 2307.2311

19. Smith KT, Cousins RJ, Silson BL, Failla ML (1978) Zinc absorp tion and metabolism by isolated vascularity perfused rat intestine. J Nutr 108: 1849-1857

20. Craft NE, Failla ML (1983) Zinc, iron and copper absorption in the streptozotocin-diabetic rat. Am J Physiol 244: E122-E128

21. Lau AL, Failla ML (1984) Urinary excretion of zinc, copper, and iron in the streptozotocin-diabetic rat. J Nutr 114: 224-233

22. Vander AJ, Victery W, Germain C, Holloway D (1983) Insulin is a physiological inhibitor of urinary zinc excretion in anesthetized dogs. Am J Physiol E536-E540

23. Cleary ML, McClain CJ, Hegarty PVJ (1979) Effect of zinc deficiency on weight and cellularity of different skeletal muscles in the post-weaning rat. $\mathrm{Br} \mathrm{J}$ Nutr 42: 487-- 795

24. Hambidge KM, Rogerson DO, O'Brien D (1968) Concentration of chromium in the hair of normal children and children with juvenile diabetes mellitus. Diabetes 17: 517-522

25. Morgan JM (1972) Hepatic chromium content of diabeatic subjects. Metabolism 21: 313-320
26. Eriksson UJ (1984) Diabetes in pregnancy: retarded fetal growth, congenital malformations and fetomaternal concentrations of zinc, copper and manganese in rat. J Nutr 114: 477-484

27. Unger RH, Grundy S (1985) Hypcrglycaemia as inducer as well as consequence of impaired islet cell function and insulin resistance: implication for the management of diabetes. Diabetologia 28: $1119-1121$

28. Sasson S, Cerasi F (1986) Substrate regulation of the glucose transport system in rat skeletal muscle. J Biol Chem 260: 79968001

29. Garvey WT, Defsky JM (1987) Glucose and insulin coregulate the glucose transport system in primary cultured adipocytes. $J$ Biol Chem 262: 189-197

Received: 20 August 1987

and in revised form: 23 February 1988

Dr. I. Raz

Department of Medicine B

Hadassah University Hospital

P O Box 12000)

Jerusalem 91120

Israel 